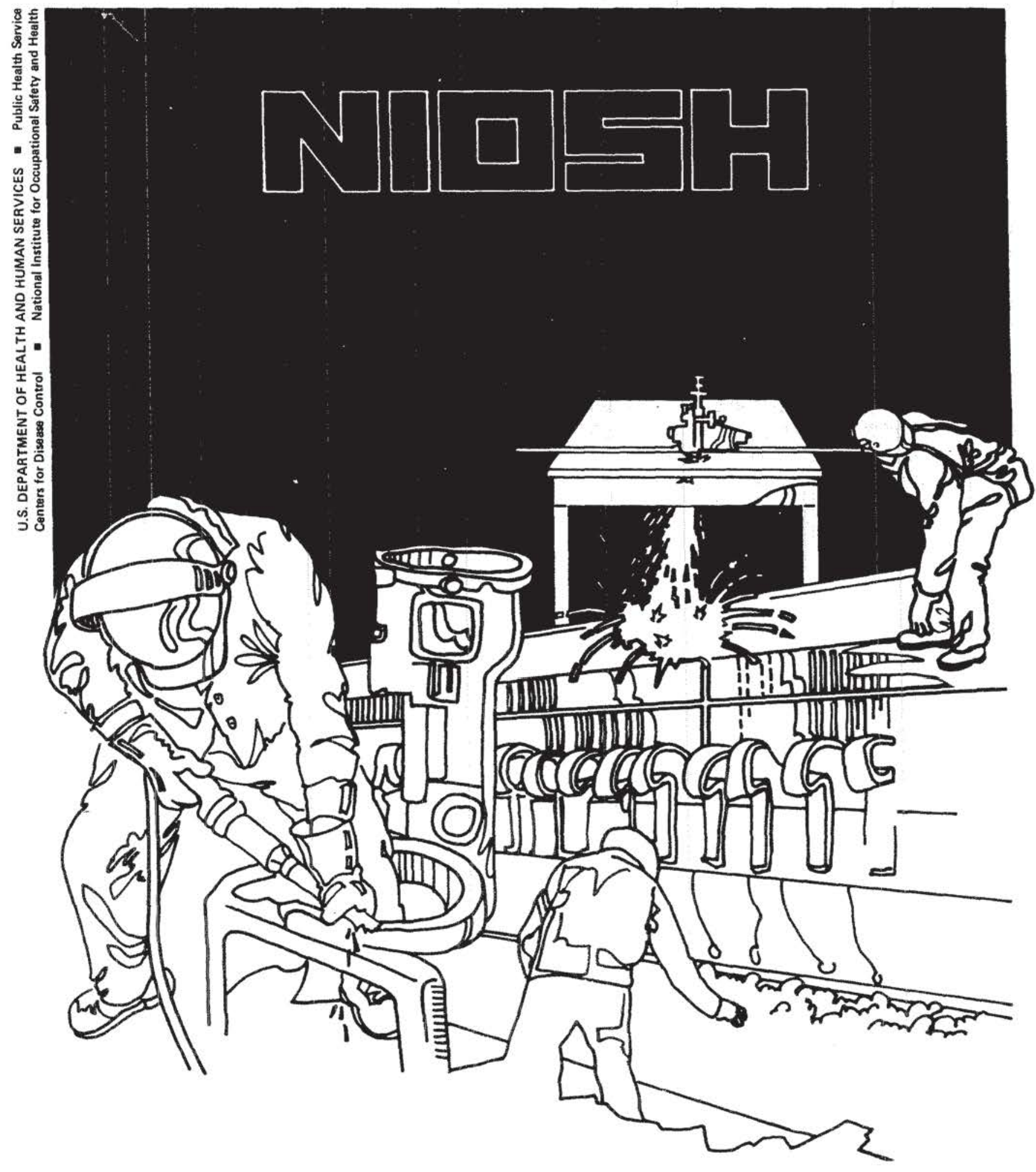

\title{
Health Hazard Evaluation Report
}

HETA 83-063-1364 LOUIS A. JOHINSON MEDICAL CENTER CLARKSBURG, WEST VIRGINIA 


\section{PREFACE}

The Hazard Evaluations and Technical Assistance Branch of NIOSH conducts field investigations of possible health hazards in the workplace. These investigations are conducted under the authority of Section $20(a)(6)$ of the Occupational Safety and Health Act of 1970, 29 U.S.C. $669(a)(6)$ which authorizes the Secretary of Health and Human Services, following a written request from any employer or authorized representative of employees, to determine whether any substance normally found in the place of employment has potentially toxic effects in such concentrations as used or found.

The Hazard Evaluations and Technical Assistance Branch also provides, upon request, medical, nursing, and industrial hygiene technical and consultative assistance (TA) to Federal, state, and local agencies; labor; industry and other groups or individuals to control occupational health hazards and to prevent related trauma and disease.

Mention of company names or products does not constitute endorsement by the National Institute for Occupational Safety and Health. 
HETA 83-063-1364

SEPTEMBER 1983

LOUIS A. JOHNSON MEDICAL CENTER

CLARKSBURG, WEST VIRGINIA
NIOSH INVESTIGATOR:

L. Piacitelli, I.H.

\section{INTRODUCTION}

A health hazard evaluation was conducted by the National Institute for Occupational Safety and Health (NIOSH) at the Louis A. Johnson (LAJ) Medical Center Histology Laboratory, Clarksburg, West Virginia, on November 11,1982 . The request was made by the hospital's Engineering Services Department.

Breathing zone and general room air samples were collected for xylene, ethanol, and formaldehyde. A health hazard did not exist at this laboratory during the time of this evaluation.

KEYWORDS: SIC 8071, histology laboratory, formalin, xylene, ethanol 
Page 2 - Health Hazard Evaluation Report No. 83-063

II. BACKGROUND

One histology technician works in the laboratory each shift. One day a week a second technician helps out in the lab. Ethanol, formalin, xylene and hematoxylin and eosin dyes are used in the preparation of tissue slides. Formalin is used as a fixative for the gross tissue specimens. Two tissue processors are used in the lab. Mineral oil, xylene, ethanol and paraffin are used in the tissue processors. In addition, one tissue processor contains approximately two pints formalin and has an exhaust hood.

Ventilation of the laboratory is provided by a duct from the general hospital ventilation system, an exhaust hood, and window mounted air conditioner. According to a histology technician, the window in the lab is kept partially open for additional air.

III. MATERIALS AND METHODS

Personal breathing zone and area samples were collected and analyzed for xylene per NIOSH Physical \& Chemical Analytical Method (P\&CAM) S-318(1).

Ambient air direct reading detector tube samples were collected for ethanol and formaldehyde. The range of measurement for formaledhyde is 0.5 to $10 \mathrm{ppm}$ and for ethanol 100 to $3,000 \mathrm{ppm}$.

IV. EVALUATION CRITERIA

Three sources of criteria are generally used to assess workroom concentrations of air contaminants: (1) NIOSH criteria for recommended standards; (2) recommended Threshold Limit Values (TLVs) and their supporting documentation as set forth by the American Conference of Governmental Industrial Hygienists (ACGIH), 1982;(3) Occupational Safety and Health Administration (OSHA) standards (29 CFR 1910.1000). NIOSH criteria and ACGIH TLVS represent the most recent and relevant recommendations and are given prominence in this evaluation. 
Page 3 - Health Hazard Evaluation Report No. 83-063

$\frac{\text { Permissible Exposures, 8-Hour Time-Weighted }}{\text { Exposure Basis ppm }}$

\begin{tabular}{|c|c|c|c|}
\hline SUBSTANCE & $\begin{array}{l}\text { NIOSH } \\
\text { RECOMMENDED } \\
\text { STANDARD } \\
\end{array}$ & TLV & $\begin{array}{c}\text { OSHA } \\
\text { STANDARD }\end{array}$ \\
\hline Forma 1 dehy de & Lowest feasible $e^{\star *}$ & $2(c)^{*}$ & $3.0,5.0(c)$ \\
\hline Xylene & 100 & 100 & 100 \\
\hline Ethanol & 1000 & 1000 & -- \\
\hline $\begin{array}{l}c-\text { ceiling } \\
\text { ppm }=\text { parts } \\
\text { * intended cha } \\
{ }^{\star} \text { NIOSH recon } \\
\text { potential }\end{array}$ & $\begin{array}{l}\text { nant per million pa } \\
1 \mathrm{ppm}(\mathrm{c}) \\
\text { that formaldehyde } \\
\text { ational carcinogen. }\end{array}$ & $\begin{array}{l}\text { f air } \\
\text { died as a }\end{array}$ & \\
\hline
\end{tabular}

Occupational health standards are established at levels designed to protect individuals occupationally exposed to toxic substances on an 8-hour per day, 40-hour per week basis over a normal working lifetime.

Formal dehyde

Exposures to concentrations between $0.1 \mathrm{ppm}$ and $5 \mathrm{ppm}$ formaldehyde can cause burning of the eyes, tearing and general irritation of the upper respiratory passages. Higher exposures, 10 to $20 \mathrm{ppm}$ may produce coughing, tightening in the chest, a sense of pressure in the head and palpitation of the heart. Exposures at 50-100 ppm and above can cause pulmonary edema, pneumonitis or death. (2)

Formaldehyde has induced a rare form of nasal cancer in both Fischer 344 rats and in B6C3F1 mice as reported in an ongoing study by the Chemical Industry Institute of Toxicology (CIIT). In a second study by New York University, formaldehyde appears to have induced the same type of cancer in Sprague-Dawley rats. Although humans and animals may differ in their susceptibility to specific chemical compounds, any substance that produces cancer in experimental animals should be considered as potentially carcinogenic to humans. Formaldehyde has also demonstrated mutagenic activity in several test systems. Although a substance cannot as yet be designated a carcinogen based solely on results of mutagenicity tests, positive results in mutagenicity tests are used as supporting evidence for identifying a potential carcinogen. (2)

Based on these results, NIOSH recommends that formaldehyde be handled, in the workplace, as a potential occupational carcinogen.(2) 
Page 4 - Health Hazard Evaluation Report No. 83-063

Xylene

Brief exposure of humans to $200 \mathrm{ppm} x y l$ ene can cause irritation of the eyes, nose and throat. Workers exposed to concentrations above $200 \mathrm{ppm}$ complain of anorexia, nausea, vomiting and abdominal pain. Exposure to high concentrations of xylene vapor may cause reversible damage to the kidneys and liver. The liquid is a skin irritant and causes erythema, dryness and defatting. Cutaneous absorption of xylene can contribute to the overall exposure.(3)

\section{Ethanol}

Irritation of the eyes and respiratory tract are not noted below 5000 ppm. (4) Exposures to a high concentration of the vapor will produce irritation of the mucous membranes, headache, nervousness, dizziness, tremors, fatigue, nausea and loss of consciousness. If the exposure is excessive and repeated, it may produce damage to the liver. When ethanol is absorbed into the body, it is rapidiy metabolized so that heavy exposure is required to build up a substantial concentration in the tissues. (5)

VI. RESULTS AND DISCUSSION

Results of the environmental sampling indicate that worker exposure to xylene, formal dehyde, and ethanol is well below the evaluation criteria levels.

Four indicator tubes were used to measure formal dehyde gas concentration. No formaldehyde gas was detected, the detection limit of the indicator tubes is 0.5 to $10 \mathrm{ppm}$.

Three indicator tubes were used to measure ethano1. A11 samples were below the indicator tube detection 1 imit of $100 \mathrm{ppm}$.

Breathing Zone \& Area Air Concentrations of Xylene

\begin{tabular}{llcr} 
Sample \# & Location & Sampling Time & ppm \\
1 & Personal & $8: 45-9: 45$ & \multicolumn{1}{c}{9.8} \\
2 & Tissue Processor & $9: 15-10: 08$ & 17.3 \\
3 & Personal & $9: 45-10: 43$ & 3.9 \\
4 & Coverslipping & $10: 15-11: 15$ & 2.1 \\
5 & Coverslipping & $11: 35-12: 25$ & 4.5 \\
6 & Personal & $12: 45-13: 50$ & 2.3
\end{tabular}

The highest breathing zone concentration measured was $9.8 \mathrm{ppm}$ which is $10 \%$ of the $100 \mathrm{ppm}$ standard. This sample was collected while the histology technician changed the xylene used in the two tissue processors, approximately three pints in one and 15 pints in the other. This appears to be the period of maximum exposure. The highest area concentration, $17.3 \mathrm{ppm}$, was collected at one of the tissue processors as the xylene was being changed. 
Page 5 - Health Hazard Evaluation Report No. 83-063

VI. RECOMMENDATIONS

Appropriate gloves should be worn when there is a possibility of skin contact with xylene, formaldehyde, and ethanol, especially when changing the chemicals in the tissue processors. Milled nitrile gloves are chemically resistant to xylene, ethanol and formaldehyde. Neoprene, natural latex or rubber and butyl gloves are ineffective against xylene and formaldehyde.

NIOSH recommends that employees who are exposed to levels of xylene above half the recommended standard of $100 \mathrm{ppm}(50 \mathrm{ppm})$ be provided with preplacement and biennial exams that include a complete biood count, routine urinalysis and appropriate liver function tests. (6) With the use of gloves and the low concentrations of xylene measured, these medical exams are not essential for histology technicians at the LAJ Med Center. However, medical exams and Taboratory tests may be appropriate for those histology technicians with complaints of headache, nausea, gastro-intestinal disturbance or nausea.

All employees should be informed of the toxicity of formaldehyde and xylene and the proper use of toxic chemicals. The noise of the exhaust hood interferes with the dictation of the pathologist's observations. Engineering services should evaluate the system and take measures to reduce the noise.

VII. REFERENCES

1. NIOSH Manual of Analytical Methods. Second Edition, Vol. 3, NIOSH 77-157-C. Apri1 1977.

2. NIOSH Current Intelligence Bulletin, No. 34, Apri1, 1981, DHHS (NIOSH) Publication No. 81-111.

3. Occupational Health Guidelines for Chemical Hazards, DHHS (NIOSH) Publication 81-123.

4. Documentation of the Threshold Limit Values, 4th Edition, American Conference of Governmental Industrial Hygienist, 1980.

5. Fundamentals of Industrial Hygiene, Second Edition, Julian B. 01ishifski, ed, 1979, National Safety Council.

6. Occupational Exposure to Xylene, HEW Publication No. (NIOSH) 75-168. 
Page 6 - Health Hazard Evaluation Report No. 83-063

VIII. AUTHORSHIP AND ACKNOWLEDGEMENTS

Report Prepared By:

Laurie Piacitelli

Industrial Hygienist

Environmental Investigations Branch

Division of Respiratory Disease Studies

Morgantown, West Virginia

Originating Office:

Mining Hazard Evaluation and Technical Assistance Program

Division of Respiratory Disease Studies

Morgantown, West Virginia

Report Typed By:

Ann Stanley

Secretary Typist

Health Hazard Evaluations

Branch

IX. DISTRIBUTION AND AVAILABILITY OF REPORT

Copies of this report are currently available upon request from NIOSH Division of Standards Development and Technology Transfer, 4676 Columbia Parkway, Cincinnati, Ohio 45226. After 90 days, the report will be available through the National Technical Information Service (NTIS), 5285 Port Roya1, Springfield, Virginia 22161. Information regarding its availability through NTIS can be obtained from NIOSH Publications office at the Cincinnati address. Copies of this report have been sent to:

1. Louis A. Johnson Medical Center

2. NIOSH Regional Office III

For the purpose of informing affected employees, copies of this report shall be posted by the employer in a prominent place accessible to the employees for a period of 30 calendar days. 